\title{
Future Trends in Worldwide Maritime Terrorism
}

By Joshua Sinai*

Today, all the warning signs indicate the highest states of alert for terrorist attacks against the maritime sector worldwide. Al-Qaeda and its allies are thought to pose the greatest danger to the maritime sector, whether against military or commercial ships of varying sizes navigating the world's waterways, or against ports and related facilities. Ports, in fact, are threatened either as actual targets for attack or as entry points for smuggled weapons, including weapons of mass destruction (WMD). A second potential component of maritime terrorism is for terrorist groups to lease ships and boats to transport weapons from a multiplicity of suppliers to their intended recipients. Finally, there is great concern that a terrorist group, such as Al-Qaeda - which has a global reach, including its own fleet of vessels - possesses the motivation and capability to launch a waterborne WMD operation against American or other ports by detonating a nuclear or radiological dispersal device, thereby threatening the life and economic livelihood of that region.

The United States and its allies - including France - are especially vulnerable to maritime terrorist attacks because of their worldwide overseas presence. Some countries, such as Israel and Sri Lanka, already have a long history of facing maritime terrorist warfare. In many of the world's waterways, states also confront the threat of maritime piracy or the transshipment of illegal narcotics. Although such criminal activities may not be directly related to maritime terrorism, there is the potential of spillover to the terrorist arena because of the increasing linkages and joint efforts between criminal and terrorist organizations.

More than 46,000 vessels and some 4,000 ports make up the world's maritime transport system. ${ }^{1}$ Cargo shipping is crucial to the well being of global commerce because, according to a recent OECD report, more than 80 percent of world trade is conducted by sea. ${ }^{2}$ However, as noted by this report, much of this maritime infrastructure is "open and flexible - attributes that make it vulnerable to terrorist attacks or misuse..."3 For these reasons, this sector "can be used to conceal weapons, or provide logistical support for terror organizations. Because ship ownership is easily concealed, the system can also serve as a source of funds for terrorists." Most alarming, a "large and well-coordinated"

\footnotetext{
* Dr. Sinai is a specialist on transnational terrorism at ANSER (Analytic Services), in Arlington, VA, and a consultant on terrorism threat/risk assessment to the corporate sector.

1 "Maritime Security Measures to Amplify Cost for Shipping," Transport Security World, 29 July 2003.

${ }^{2}$ Ibid.

3 Ibid.

4 Ibid.
} 
attack against this sector that is could severely disrupt the entire maritime transportation system, shutting much of it down. ${ }^{5}$ In fact, according to a study that simulated a major attack on the U.S. maritime infrastructure, the cost of such an attack could reach $\$ 58$ billion. $^{6}$

Thus, the threat of maritime terrorism is particularly significant today. Just like ground and aviation terrorist warfare, groups that engage in maritime warfare seek to cause mass casualties and damage the economic welfare and security of their state adversaries. ${ }^{7}$ For example, when terrorists belonging to the Egyptian Al-Gama'a al-Islamiyya (also known as the Islamic Group) attacked cruise ships along the Nile River on four occasions from 1992 to 1994, tourists kept away from Egypt. ${ }^{8}$ In the Philippines, when the Abu Sayyaf group attacks cargo vessels or abducts foreigners from a tourist resort (as it did in 2001), it has an impact on the entire country's trade and economy. In Somalia, when militiamen hijack foreign ships sailing off the country's coastline, vessels steer away from that region. The January 1996 seizure of a Turkish passenger ferry by pro-Chechen terrorists exposed the vulnerability to terrorist attack of passenger ferries in the Bosporus, as well as the Aegean and Black Seas astride the straits. ${ }^{9}$ The October 2000 suicide bombing of the USS Cole by Al-Qaeda operatives in the Yemeni port of Aden, killing seventeen U.S. servicemen; the thwarted plot in June 2002 by Al-Qaeda operatives to bomb American and British warships, as well as commercial oil tankers, in the Gibraltar Strait; and the 6 October 2002 suicide bombing of the French tanker Limburg in the Gulf of Aden - all served as stark reminders that the world's military and economic vessels represent "trophy" targets of opportunity to terrorist groups. In response, Western passenger cruise ships avoid sailing to the eastern Mediterranean or other Middle Eastern destinations, which had been extremely popular tourist destinations in past years.

This essay's objective is to present an overview and highlight the latest and future trends in worldwide maritime terrorism. This is important for several reasons. In terms of tactics, just as in the September 11, 2001 exploitation by Al-Qaeda operatives of the "traditional" terrorist tactic of hijacking aircraft to strike at ground targets, maritime security officials need to anticipate a resurgence in terrorist targeting of maritime vessels and related transportation nodes, which used to be popular terrorist targets of opportunity in the 1970s and 1980s. As a result of such trends, today there is widespread concern that innovation by terrorist groups and their sponsors in developing new maritime terrorist tactics

\footnotetext{
${ }^{5}$ Ibid.

${ }^{6}$ The simulated maritime terrorist attack scenario was conducted by the Conference Board and Booz Allen Hamilton; ibid.

${ }^{7}$ Rohan Gunaratna, “Trends in Maritime Terrorism: The Sri Lankan Case," Lanka Outlook, Autumn 1998.

${ }^{8}$ John Sitilides, "U.S. Strikes Expose Emerging Regional Threats," The HR-Net Forum [The Washington Monitor], 28 August 1998.

${ }^{9}$ Ibid.
} 
and weapons will cause increasing destructiveness in terms of human casualties, physical damage, and economic costs against the maritime sector. Such new tactics and weaponry may also become increasingly difficult to detect because of terrorist groups' utilization of stealth vessels and other evasive techniques and technologies. It is hoped that a comprehensive understanding of these new trends will alert all those associated with the critical maritime transportation infrastructure - whether governmental or private, military or commercial - to adopt the necessary defensive and preemptive measures to prevent such attacks from occurring, especially those that might involve weapons of mass destruction.

This essay is organized into five parts:

- An overview of the linkages between maritime terrorism and piracy, arms, narcotics, and human smuggling.

- An examination of terrorist groups with a maritime warfare capability.

- An overview of regional maritime "hot spots."

- A partial list of potential maritime terrorist targets, focusing on U.S. maritime assets.

- An assessment of future maritime terrorist trends.

The concluding section summarizes some of the new trends in maritime terrorism that require situational awareness and prevention.

\section{Linkages Between Maritime Terrorism, Piracy, Arms, Narcotics, and Human Smuggling}

Acts of sea piracy, the smuggling of narcotics, arms and humans via sea routes, and the use of waterways by terrorist groups are interconnected and need to be viewed as part of the increasingly frequent linkages between maritime criminal activities and terrorism.

\section{Maritime Piracy}

Piracy at sea is considered an international crime. It is also a form of terrorism because, like terrorism, it employs violence to target ships' crews, passengers, and ship owners for commercial, and in certain instances political gains. ${ }^{10}$ Maritime piracy is interrelated with terrorism because, as Philippine Foreign Minister Teofisto Guingona said at a recent ASEAN conference, the "modernday version" of piracy has "political undertones although employing traditional ways, including kidnapping for ransom. It is sometimes linked to the secessionist aspirations of some elements in society, or simply Muslim militancy." 11 The Islamic separatist Abu Sayyaf movement operating in the southern

\footnotetext{
${ }^{10}$ Commander Vijay Sakhuja, "Challenging Terrorism at Sea," No. 679, 19 January 2002, at http://www.ipcs.org/issues/newarticles/679-ter-sakhuja.html.

11 “ASEAN, EU Experts Discuss Fighting Terrorism at Sea,” AFP, 25 February 2002
} 
Philippines is an example of a terrorist group that also engages in kidnapping, hijacking vessels, or using vessels to abduct foreign hostages in cross-border raids. It is also highly dangerous because of its links to Al-Qaeda.

Major regions of sea piracy include the South China Sea, Indonesian and Philippine waters, Bangladesh, Malacca Straits, India, Ecuador, and the Red Sea, with the Bay of Bengal-Malacca Straits region considered to be piracy's primary "center of gravity." 12 In 2000, there were 471 cases of maritime piracy and armed robbery against ships. ${ }^{13}$ Nearly half occurred in the busy sea lanes of Southeast Asia, the Malacca Strait, and the Indian Ocean. Pirates also became more deadly, with 72 crewmembers killed, 129 wounded and 5 others missing. ${ }^{14}$ This figure represents a 57 percent rise from the previous year. ${ }^{15}$

\section{Terrorist Use of Maritime Vessels to Smuggle Narcotics}

Narcoterrorism refers to the resort by terrorists to the production and/or transshipment of narcotics to finance their operations, as well as the employment of terrorist tactics by drug traffickers to keep government security and law enforcement forces from interfering with their operations. ${ }^{16}$ Evidence of terrorist (or guerrilla group) involvement in drug trafficking can be found in Colombia, Peru, Lebanon, Central Asia (including Afghanistan), Burma, Thailand, Sri Lanka, and other nations.

Colombia is at the center of the international cocaine trade, with enormous profits generated by the vast shipments of drugs flowing out of the country by air, river, or by sea from its coastal regions. Fishing vessels, speedboats, and commercial cargo ships transport large quantities of narcotics from Colombia to neighboring countries and directly to the United States and Europe. The drugs are usually hidden in containerized cargo, bulk cargo, or hidden compartments built into ships. The cargo is loaded or off-loaded either in port or using speedboats while at sea.

The Colombian FARC, which combines terrorist and criminal activities in its operations, is considered the world's preeminent narcotrafficking terrorist organization. Together with its criminal narcotrafficking counterparts, it is part of a sophisticated worldwide logistical infrastructure and supply network. In terms of its equipment, the FARC deploys a mix of light aircraft to parachute cocaine drops to waiting boats and ocean-going yachts and other vessels, and uses the latest technology, including the Global Positioning System (GPS), to organize yacht-to-yacht drug transfers (called "coopering", a process by which groups can evade customs checks as the transatlantic vessels, which are gener-

\footnotetext{
${ }^{12}$ Ibid.

${ }^{13}$ Ibid.

${ }^{14}$ Ibid.

${ }^{15}$ Michael Binyon, "Deadly, Growing Scourge of Seas," The Times [London], 7 December 2001.

${ }^{16}$ Sean K. Anderson and Stephen Sloan, Historical Dictionary of Terrorism (Lanham, MD and London: The Scarecrow Press, 2002), 341.
} 
ally checked, can dock "clean"). ${ }^{17}$ The local craft onto which the drugs are transferred for the last smuggling leg can then put into port with less likelihood of arousing suspicion. ${ }^{18}$

The Colombian drug trafficking organizations, such as FARC, generate billions of dollars in annual revenues, which they use to purchase the services of foreign technical specialists. These foreign specialists, in turn, provide these groups with highly versatile and innovative tactics, technologies, and equipment. This was demonstrated by the seizure on 7 September 2000 by the Colombian National Police of a partially constructed, 100-foot steel-hulled submarine from a warehouse outside Bogotá, Colombia. The \$20 million submarine, if completed, could have been used to transport up to ten metric tons of illicit drugs from Colombia to remote off-load sites in Latin America and the Caribbean, while it remained at snorkel depth the entire time. ${ }^{19}$ Russian organized crime was suspected of involvement in this submarine project because Russian instruction manuals, with Spanish translations, were found in the warehouse where the submarine was being built. ${ }^{20}$ Although drug smugglers have used "semi submersibles" in the past, law enforcement officials do not expect them to become a significant threat in the future. ${ }^{21}$ However, the close linkages between Colombian drug trafficking groups and Middle Eastern terrorist groups (and drug smugglers) such as Hezbollah, or even European groups such as the IRA, means that information sharing, and even cross-training, between them are contributing factors in advancing and upgrading their tactics and weaponry.

\section{Terrorist Use of Vessels to Transport Weapons}

As mentioned earlier, a second component of maritime terrorism is terrorist use of vessels to transport weapons. Several highly publicized incidents have occurred in recent years involving terrorists' use of boats and ships to smuggle weapons. For example, Al-Qaeda reportedly has extensively used cargo ships to transport its conventional weapons and explosives, including the explosives used in the simultaneous bombings of two American Embassies in East Africa in 1998. ${ }^{22}$ The trend of terrorists' use of vessels to transport their equipment is likely to escalate with the continuous need by terrorist groups to transport their equipment worldwide, as well as to expand their reserves of arms and ammunition by having them transported to their safe havens.

\footnotetext{
17 “Global Drugs Ring Shattered,” [Manchester] Guardian, 14 June 2002.

18 Ibid.

${ }^{19}$ Statement of Donnie R. Marshall, Administrator, Drug Enforcement Administration, before The House Judiciary Committee, Subcommittee on Crime, 13 December 2000.

${ }^{20}$ Ibid.

${ }^{21}$ State Department International Narcotics Control Strategy Report: Colombia, 1 March 2001.

${ }^{22}$ Philip Shenon, "U.S. Expands Plan for Cargo Inspections at Foreign Ports," New York Times, 12 June 2003.
} 


\section{$\underline{\text { Santorini Incident }}$}

On 6 May 2001, the Israeli navy captured the Santorini fishing vessel carrying weapons, including Katyushas, anti-aircraft rockets, mortars of various calibers, and massive quantities of ammunition, en route from Lebanon to the Gaza Strip. ${ }^{23}$ The Israeli seizure resulted from a joint operation by the intelligence corps, the navy, and the air force. The Israeli military claimed that the weapons were intended for Palestinian terrorist groups for use against Israeli targets. The ship had set off from the port of Tripoli in northern Lebanon, and was headed in international waters to a rendezvous in the Gaza Strip until it was detained in the Mediterranean off the shores of northern Israel, outside of Israeli territorial waters. Some of the weapons, all of which were carefully packaged in waterproof wrappings, had been packed into barrels that were roped together. Israeli newspapers have published two versions of how the arms would be transported. According to one version, the aim was to drop the barrels into the sea at a designated point off the Gaza coast, where they would be retrieved by boats manned by Palestinian security services. According to the second version, the vessel was to be met by a fishing boat manned by Egyptian fishermen, who would then transfer the arms to a Palestinian fishing boat that would carry them to Gaza.

A crew of four Lebanese smugglers operated the Santorini fishing vessel. It was commissioned by a dissident Palestinian group led by Ahmed Jibril - the Popular Front for the Liberation of Palestine-General Command (PFLPGC), a Damascus-based group that had intended to step up attacks on Israel. ${ }^{24}$ The vessel's crew surrendered without any resistance and immediately told the Israeli naval officers what they were transporting. Following the vessel's capture, Jibril, speaking from his home in Damascus, Syria, said his group would continue smuggling weapons and munitions into Palestinian Authority-held areas.

Because Katyushas have long been used by the Lebanese Hezbollah, and Hezbollah has previously engaged in the maritime smuggling of arms to Gaza, Israeli analysts pointed to a possible connection between the PFLP-GC and Hezbollah. During the last decade, for example, Jibril had forged links with Iran and Islamic radicals, which would indicate that Iran, Hezbollah's patron, was likely informed of this mission. The Syrian government, Jibril's direct sponsor, also likely was informed of the operation.

Moreover, because the PFLP-GC is a relatively small organization, whose activities are nearly all conducted abroad, including in Syria and Lebanon, it has nearly no presence in the West Bank and Gaza. It is therefore likely that such a large quantity of weapons was meant not only for the mem-

\footnotetext{
${ }^{23}$ Amnon Barzilai, Daniel Sobelman, and Amira Hass, "Arms Boat Made Three Visits to Gaza," Ha'aretz, 9 May 2001.

${ }^{24}$ Danny Rubinstein, “Analysis: Weapons Were Meant for Many Fighters,” Ha'aretz, 8 May 2001.
} 
bers of Jibril's organization in Gaza, but for larger groups in Gaza as well, especially those comprising the various "resistance committees" - Fatah's Tanzim/al Aqsa Martyrs' Brigades, Hamas, and Palestinian Islamic Jihad, who initiate the majority of the terrorist incidents against Israel. It is these groups that possess the operational capability to distribute such a large quantity of sophisticated weapons to trained persons who are capable of using them.

According to Israeli analysts, this was not the first time that this method has been used. Reportedly, in the past, similar shipments of arms in barrels had been unloaded onto beaches in Gaza and were hidden away in warehouses. In fact, the Santorini was apparently well known to Israeli security forces as a smugglers' vessel in the 1980s and 1990s, and several of the crew on board had been captured as drug smugglers in the past by Israeli navy patrols. As a further indication that the Santorini incident was not unique, the packing of the weapons by its crew was done in a professional manner, by people used to dealing with arms, and they appeared very familiar with smuggling armaments to Gaza. Moreover, prior to this incident, the Palestinian Authority had requested that Israel ease life for the local population in Gaza by expanding the stretch of water in which Palestinian boats are allowed to fish, thereby, indirectly, also facilitating the maritime transport of arms.

\section{$\underline{\text { Karine A }}$}

Proof that the Santorini affair was officially sanctioned by the Palestinian Authority, as part of a larger, continuous maritime arms smuggling effort, came in the early morning of 3 January 2002, when Israeli Defense Forces (IDF) naval commandos seized the 4000-ton Karine $A$ freighter ship in the Red Sea, some 300 miles off the Israeli coast. The ship was carrying 83 watertight plastic crates containing a variety of mainly Iranian-made weaponry, including short- and long-range Katyusha rockets, anti-tank missiles, mortars, mines, 1,500 kilograms of high explosives, sniper rifles, shotguns, and other equipment, including inflatable Zodiac boats, cylinders, and diving equipment. ${ }^{25}$

According to the ship's captain, Omar Akkawi, a colonel in the Palestinian naval police (whom the Israelis arrested), the arms were loaded on the ship at an island off Iran's coast in the Persian Gulf, with the waterproof crates intended to be transferred to smaller boats near the Egyptian port of Alexandria. They would then be transferred again near the Gaza coast, where they would be picked by Palestinian navy officers disguised as fishermen. ${ }^{26}$

Several factors made this smuggling operation extremely significant. First, its aim was to substantially upgrade the Palestinian forces' military capability with a huge quantity of long-range weaponry and explosives, as well as to provide them with a maritime terrorist capability with the Zodiacs and div-

25 “Weapons Ship Mystery Deepens," BBC News, 10 January 2002. www.news.bbc.co.uk ${ }^{26}$ Ibid. 
ing equipment. Second, it violated the terms of the interim peace agreements between the Palestinian Authority and Israel, under which the Palestinian Authority is allowed only a limited number of small arms, such as rifles, for its police forces, but no heavy weapons, long-range rockets, or explosives. ${ }^{27}$ Third, according to Israeli authorities, the ship was part of a smuggling operation coordinated by the Palestinian Authority, Hezbollah, and Iran. In fact, the Israelis implicated a senior Hezbollah security officer, Imad Mughniyeh, who also serves as liaison between Iran and Hezbollah, as playing a leading role in the Karine $A$ affair. ${ }^{28}$ Mughniyeh is also on the FBI's most wanted list for his alleged role in kidnapping Western hostages in Beirut during the 1980s and the hijacking of TWA flight to Beirut.

In retaliation for the Karine $A$ smuggling operation, on 12 January 2002 Israeli military boats and divers attacked a Palestinian naval police base in Gaza City, destroying two patrol boats. One of the boats, named Jandala, was believed to be linked to the arms smuggling operation. In fact, the Karine A's captain and senior officer had reportedly previously served on the Jandala.

\section{'Baltic Sky' Incident}

On 22 June 2004, Greek authorities seized nearly 700 tons of explosives, mainly TNT, as well as 8,000 detonators and fuses, on board the vessel Baltic Sky. ${ }^{29}$ The ship, built in 1966, and originally sailing under the Russian and Ukrainian flags until July $2001,{ }^{30}$ sailed under the Comoros flag of convenience, although reports linked it with an Ireland-based company. The ship had set sail from Tunisia on 12 May en route to Sudan - but had been sailing around the Mediterranean for six weeks - when Greek special forces stormed on board, off Greece's western coast. ${ }^{31}$ The Greek Coast Guard had monitored the ship for five days, following a tip from international intelligence agencies that it was carrying suspicious cargo. ${ }^{32}$ The ship's crew - five Ukrainians, including the captain, and two Azeris - were placed in custody. The Sudanese government claimed that the explosives - ammonium nitrates - had been ordered by a Sudanese chemical company and were intended for civilian use. ${ }^{33}$

The ship's weapons cargo was described as a floating "atomic bomb" by Greek Shipping Minister George Aromeritis. ${ }^{34}$ The cargo was described as "Anfo," an explosive made by mixing ammonium nitrate with fuel oil. ${ }^{35}$ Greek

\footnotetext{
27 Ibid.

28 Ibid.

29 "Crew Held Over Explosives Cargo," BBC News, 25 June 2003. www.news.bbc.co.uk

30 "Explosives Ship Intercepted," Ports \& Shipping, 24 June 2003.

31 "Crew Held Over Explosives Cargo."

${ }^{32}$ Brian Williams, “Greece Links Seized Ship's Explosive Cargo to Sudan,” Reuters, 23 June 2003.

33 "Crew Held Over Explosives Cargo."

34 Ibid.

${ }^{35}$ Penny Spiller, “Storm Surrounds the Ship's Cargo,” 24 June 2003. www.news.bbc.co.uk
} 
authorities were concerned about the cargo because, although commonly used for mining and quarrying, Anfo is also used by terrorist groups, such as the IRA, in bomb attacks. ${ }^{36}$ Contributing to concern over the ship was the fact that Sudan, the cargo's point of destination, is on the U.S. State Department's list of state sponsors of terrorism, and the cargo's discovery came amid heightened terrorism alerts in the region.

As demonstrated by these cases, terrorist groups and their supporters use ships to transport weapons and equipment. In fact, another transportation mode needs to be addressed: the use of containers on board vessels to smuggle weapons and devices, including weapons of mass destruction, as well as human operatives. In October 2001, for example, Italian authorities discovered an alleged Al-Qaeda operative of Egyptian nationality hiding in a shipping container that was bound for Halifax, Nova Scotia. ${ }^{37}$ The container was equipped with a bed and bathroom, and contained airport maps and security passes. ${ }^{38}$ Little other information was obtained because the operative disappeared after being granted bail.

\section{Terrorist Groups with Maritime Capability}

A spectrum of terrorist groups worldwide is operationally capable of employing maritime means either to transport military equipment or conduct terrorist attacks.

\section{LTTE}

The Liberation Tigers of Tamil Eelam (LTTE) are considered to possess the world's preeminent maritime terrorist capability. The LTTE has built up "a brown (coastal), green and blue (deep sea) water maritime capability." 39 The brown and green water craft are launched from land by the group's Sea Tiger forces, with an estimated strength of 2,000-3,000 cadres..$^{40}$ The Sea Tigers employ machine guns, rocket propelled grenade launchers, radar, and speedboats to attack their adversaries. ${ }^{41}$ This three-pronged maritime capability has provided them with the tactical ability to utilize their maritime fleet to covertly import military equipment from foreign suppliers, board vessels without permission, attack and destroy Sri Lankan naval boats and ships, and damage or hijack foreign-owned civilian vessels in Sri Lankan waters, particularly when they are transporting equipment that the group needs. ${ }^{42}$ The LTTE's maritime capability is so potent that it even has established a "super secret Exclusive

\footnotetext{
${ }^{36}$ Ibid.

${ }^{37}$ Shenon, "U.S. Expands Plan for Cargo Inspections at Foreign Ports."

${ }^{38}$ Ibid.

${ }^{39}$ Gunaratna, "Trends in Maritime Terrorism: The Sri Lankan Case."

${ }^{40}$ Ibid.

${ }^{41}$ Ibid.

${ }^{42}$ Ibid.
} 
Economic Zone-Marine Logistics Support Team,"43 consisting of Mirage-class fiberglass vessels that are fifty feet long and sixteen feet wide and capable of long-range operations. ${ }^{44}$ These vessels are employed to provide protection to the group's ships when they sail toward Sri Lanka's maritime border.

Considered to be the most technologically and tactically innovative of the world's maritime terrorist groups, the LTTE's modus operandi is likely to be emulated by other groups. The LTTE shares with other maritime terrorist groups the political and economic motivation to engage in this type of warfare, which impinges on its larger adversary's efforts to achieve economic prosperity and security. ${ }^{45}$ If the current peace process between the Sri Lankan government and the LTTE breaks down, the LTTE's maritime warfare operations will surely resurface.

\section{Al-Qaeda}

Osama bin Laden's Al-Qaeda organization is a major maritime terrorist actor. According to a March 2002 report by Norwegian intelligence, Al-Qaeda owned about twenty-three vessels, including ocean passage-capable merchant vessels, which are operated or chartered through front companies in Liberia, Panama, and the Isle of Man. ${ }^{46}$ This figure may or may not include other ships chartered, but not directly owned, by Al-Qaeda. Additionally, bin Laden's brother-in-law reportedly operates a fishing boat business in Madagascar and Asia that might provide additional logistical support to future Al-Qaeda maritime operations.

Al-Qaeda operatives have staged several major maritime terrorist attacks. These include the spectacular waterborne suicide bombing of the USS Cole in October 2001, in the Yemeni port of Aden, which killed seventeen American sailors, and the October 2002 small boat suicide bombing of the French supertanker Limburg off the Yemeni coast.

In addition to actual attacks, Al-Qaeda operatives have plotted attacks on several high-profile maritime targets that were foiled during their pre-incident preparation phases. These plots include a conspiracy by one of Al-Qaeda's Singapore satellite cells to target U.S. naval assets, a plot that fortunately was foiled when Singaporean authorities in December 2001 detained thirteen suspects who were members of a clandestine Jemaah Islamiyah or "Islamic Group" cell. ${ }^{47}$ Although the main targets of this plot included the U.S. Embassy and the

\footnotetext{
${ }^{43}$ Ibid.

44 Ibid.

45 Ibid.

${ }^{46}$ The estimates of vessels under al Qaida's control are based on Commander Vijay Sakhuja, "Challenging Terrorism at Sea," 19 January 2002, No. 679, http://www.ipcs.org/issues/newarticles/679-ter-sakhuja.html; and Intellibridge, "United States - Security: A Progress Report on U.S. and International Approaches to Maritime Security," Homeland Security Monitor, 10 July 2003.

${ }^{47}$ United States Department of State, Patterns of Global Terrorism 2001 (Washington, D.C.: Department of State, May 2002), 21.
} 
residences of U.S. military personnel in Singapore, the cell had reportedly "planned to attack several U.S. naval vessels moored off the coast of Singapore." 48 The Singapore plot was followed in May 2002 by the arrest by Moroccan authorities of three Saudi members of an Al-Qaeda cell that had planned to attack American and British naval ships in the Straits of Gibraltar. ${ }^{49}$ According to Moroccan authorities, the Al-Qaeda operatives had planned to sail from Ceuta and Melilla, the Spanish enclaves on Moroccan territory, using inflatable Zodiac speedboats loaded with explosives to launch suicide attacks on the ships patrolling the straits. ${ }^{50}$

Other instances of intentions by Al-Qaeda to carry out maritime attacks include a report that its operatives were making their way toward southern California aboard a merchant ship, with Catalina Island - about twentythree miles off the California coast near Los Angeles - mentioned as a possible destination. ${ }^{51}$

\section{Hezbollah}

Hezbollah, the Lebanese terrorist group, has either plotted or been linked to various maritime terrorist operations, including sea-borne weapons smuggling. Hezbollah is an indigenous Lebanese group that is sponsored by the Iranian government. Most of its terrorist operations are directed at Israel, its primary adversary. The majority of its operations take place on land. However, in the late 1990s, according to Singapore's Internal Security Department, a Hezbollah cell had plotted to bomb American and Israeli ships docked in Singapore. ${ }^{52}$ To accomplish this mission, Hezbollah operatives recruited five Singaporean Muslims to assist with surveillance and logistics preparations. ${ }^{53}$ Interestingly, Hezbollah's plan called for filling a small boat with explosives and ramming it into a ship in the Singapore Straits or in harbor - the same modus operandi that Al-Qaeda later employed to bomb the USS Cole in Yemen. ${ }^{54}$ According to the Israeli Institute for Counterterrorism, the similarity of the blue prints used by Hezbollah and AlQaeda was not "coincidental," but part of a pattern of long-standing operational cooperation. ${ }^{55}$ In fact, Hezbollah may have provided Al-Qaeda with explosives training that may have played a role in Al-Qaeda's 1998 bombings of the American embassies in East Africa, as well as the USS Cole bombing. ${ }^{56}$

\footnotetext{
${ }^{48}$ Ibid.

49 “Morocco 'Uncovers al Qaeda Plot,” BBC News, 11 June 2002. www.news.bbc.co.uk

${ }^{50}$ Ibid.

${ }^{51}$ Charles Feldman, "FBI: Terrorists May Try to Arrive by Sea," CNN.Com, 19 June 2002.

${ }^{52}$ Institute for Counterterrorism [ICT - Herzliya], "Hizballah Planned to Attack U.S. and Israeli Ships in Singapore," [no date], http://www.ict.org.il/spotlight/det.cfm?id=790.

${ }^{53}$ Ibid.

${ }^{54}$ Ibid.

${ }^{55}$ Ibid.

${ }^{56}$ Ibid.
} 
As discussed earlier, Hezbollah served as one of the coordinators for the Karine A smuggling operation, which was intercepted by Israeli naval commandos in January 2002.

\section{Other Middle Eastern Terrorist Groups}

Several other Middle Eastern terrorist groups reportedly are interested in developing a maritime capability, such as the Egyptian Al-Gama'a al-Islamiyya and the Egyptian Islamic Jihad, while other groups, such as the Popular Front for the Liberation of Palestine-General Front, which is highly innovative in its tactics, contracts its maritime transportation enterprises to other groups, as demonstrated in the May 2001 Santorini operation.

\section{Abu Sayyaf Group}

The Filipino radical Islamic Abu Sayyaf Group (ASG) employs sea vessels to carry out some of its kidnapping and hijacking operations. Because of the ASG's maritime warfare capability, the Philippines' maritime special forces are being trained by the U.S. military to upgrade their counterterrorism capabilities. As a result, it can be expected that the ASG's maritime capability will gradually diminish. The increasing effectiveness of the Philippines' special forces was demonstrated on 21 June 2002, when they tracked down and killed Abu Sabaya, one of ASG's top leaders, killing him and two of his men (with four others surrendering) as they were fleeing Mindanao island in a boat. ${ }^{57}$

\section{High Risk Regional Waterways}

\section{The Middle East}

Currently, the Middle East is undergoing a resurgence in maritime terrorist activity. The following indications and warning factors and observables are likely to cause new motivations and triggers for Middle Eastern terrorist groups to attack U.S., Israeli, and Western shipping interests either in the Middle East or elsewhere, including the U.S. homeland:

- Sharpening escalation in Arab-Israeli violence and instability.

- Using maritime warfare to discourage the U.S. and its allies from transporting supplies to rebuild Iraq's infrastructure, as well as to pressure the U.S. to withdraw from bases in the Persian Gulf.

- Seeking revenge against the U.S.-led allied military actions in Afghanistan and Pakistan against Osama bin Laden's Al-Qaeda network and the Taliban, including detaining their fighters in U.S. and Western prisons.

57 “Abu Sayyaf Leader Believed Killed," Guardian Unlimited, 21 June 2002. www.guardian.co.uk 
- Demonstrating that Al-Qaeda still possesses a global reach by attacking U.S. vessels and seaports.

- The success of previous attacks, particularly the bombings of the USS Cole and the Limburg supertanker, in terms of the damage they caused and the ensuing publicity in influencing terrorist groups to launch further maritime attacks.

The Middle East's high risk regions cover coastal countries with a proliferation of radical subcultures such as Egypt, Lebanon, the Palestinian Authority's Gaza Strip, and Yemen, or directed by governments that actively sponsor terrorist groups, such as Iran, Iraq, Libya, and Sudan, or countries marked by internal anarchy whose coastlines border the region, such as Somalia.

The volatile Persian Gulf region is especially risky, particularly because of the U.S. naval presence in Bahrain and the U.S. role in reconstructing Iraq's infrastructure. American vessels in a Yemeni port are at great risk because the country is widely considered a crossroads for various international terrorist movements such as bin Laden's Al-Qaeda network and various Egyptian groups. To sabotage further progress in the Arab-Israeli peace process, Iranian-backed terrorist groups, such as Hezbollah and Palestinian rejectionist groups, are likely to carry out maritime attacks against U.S. vessels in the Persian Gulf and the eastern Mediterranean.

Lebanon is a haven for terrorist groups because of the protection offered to them by the Syrians, with Iranian support, in the form of unrestricted movement, military bases, and training facilities. As a result, terrorist groups use the country as a staging area for their attacks, including maritime attacks against Israel, or the use of Lebanese ports and coastline as an embarkation point to smuggle weapons to Palestinian Authority-controlled areas in the Gaza Strip. In the near term, Hezbollah, either directed by or acting independently of Iranian government support, is likely to use the Lebanese coastline to launch maritime attacks against Israel. Rejectionist Palestinian groups might exploit their access to the Gaza Strip coastline (as well as the Lebanese coastline) to launch maritime attacks against Israeli and allied U.S. vessels. This was demonstrated on 7 November 2000, when a Hamas suicide operative in a fishing boat attempted to attack an Israeli patrol craft north of Rafah in the Gaza Strip; ${ }^{58}$ fortunately for Israel, the explosive-laden Hamas boat was identified by the patrol craft and sunk before it could damage the Israeli craft. As mentioned previously, the Palestinian Authority had attempted on a number of occasions to smuggle an assortment of weapons into the Gaza Strip either from Lebanon or Iran via the sea.

\footnotetext{
${ }^{58}$ Rohan Gunaratna, "Sea Tiger Success Threatens the Spread of Copycat Tactics," Jane's Intelligence Review (March 2001): 12.
} 
The Strait of Gibraltar and the Mediterranean are considered places of potential threats against Western shipping interests, whether military or commercial. In October 2001, NATO initiated Active Endeavor, a maritime anti-terrorism operation, covering the Mediterranean. ${ }^{59}$ As part of this operation, NATO deployed military escort vessels to protect allied civilian ships through the Strait of Gibraltar at the entrance to the Mediterranean Sea. ${ }^{60}$ The U.S. Sixth Fleet in the Mediterranean is on high alert for possible terrorist attacks against its vessels.

In the Gulf of Aden, ships and yachts have reported attacks and attempted attacks while transiting the vicinity of Socotra Island. In the Gulf of Aden, for example, on 12 April 2001, three pirates in a wooden boat reportedly approached the Daisy Duck yacht and ordered it to stop. When the yacht increased speed, the pirates shot at the yacht using a machine gun. The yacht broadcast a distress call, and when its owner returned fire with his pistol, the pirate boat withdrew. As mentioned earlier, in October 2002 the French oil tanker Limburg was attacked by an Al-Qaeda unit in the Gulf of Aden.

Ships in the port of Aden have reported numerous burglaries and hostile boardings. On 16 May 2001, a Bahamian-flagged tanker docked in the Yemeni port of Aden was attacked by criminals who gained access to the radio room, whereupon they stole a laptop computer, two printers, and a fax machine. No crew injuries were reported.

On 20 January 2001, eight small boats, with six to seven men in each, approached an unidentified tanker. These boats proceeded to follow the tanker at a distance of fifty meters. The tanker's crew was alerted and the boats withdrew towards Djibouti.

Vessels transiting near the coast of Somalia are at extreme risk because of acts of piracy by Somali gangs. On the strategic route on the Horn of Africa along the southern approaches to Bab el-Mandeb and en route through the Red Sea and Suez Canal, members of Somali-based militia groups are reported to employ high-speed craft to attack and intimidate yachts and merchant vessels transiting in the Indian Ocean. These militias attack yachts with small arms, mortars, and rockets, seizing the vessels and holding their occupants for ransom.

The Malacca Straits, situated between the northern tip of the island of Sumatra and Malaysia, are one of the world's busiest shipping lanes. They are also considered among the world's most dangerous maritime routes, with vessels passing through these waterways often attacked by pirates. ${ }^{61}$ In July 2002 , for example, rebels in Indonesia's Aceh province hijacked a ship that was sup-

\footnotetext{
${ }^{59}$ Helena Smith, "NATO 'Terror' Tipoff on Explosives Ship Sailing to Sudan,” The Guardian, 24 June 2003.

${ }^{60}$ Chris Morris, "Terror Fears Spark Ship Escorts," BBC News, 17 March 2003. www.guardian.co.uk ${ }_{61}$ "Nine Oilrig Seamen Kidnapped in Malacca Straits, Officials Say," Industrial Fire Journal (July 2002), at http://www.industrialfirejournal.com/industry news.htm.
} 
plying food and safety equipment to offshore oil rigs in the Malacca Straits, and then kidnapped nine of its crew members.

Any discussion of high-risk waterways must include the waterways navigated by oil tankers, since an estimated 75 percent of the world's oil is transported by sea. According to a report on "World Oil Transit Chokepoints," "oil transported by sea generally follows a fixed set of maritime routes," along which oil tankers must pass through several geographic narrow channels, or "chokepoints." 62 Important maritime chokepoints include the Strait of Hormuz, the Strait of Malacca, the Panama Canal, the Bab el-Mandeb passage from the Arabian Sea to the Red Sea, and the Suez Canal. What makes these chokepoints significant is that they are "susceptible to pirate attacks and shipping accidents in their narrow channels." 63 Oceangoing oil tankers, which deliver imported crude and other liquid products, are especially vulnerable to terrorist attack in these chokepoints, as demonstrated by Al-Qaeda's suicide bombing of the French oil tanker Limburg in October 2002. This attack was part of Al-Qaeda's overall strategy of targeting of oil tankers, as demonstrated by its plot in June 2002 to attack British and American naval ships and commercial oil tankers passing through the Strait of Gibraltar.

\section{Potential Maritime Targets}

U.S.-flagged naval or commercial vessels represent high-value targets to terrorist groups not only because of the enormous publicity that such attacks generate, but because the size of these vessels and the difficulty of protecting them make them "soft targets." Other likely maritime targets range from U.S. and Western maritime economic facilities in the Middle East, Africa, or the South/East Asian regions, such as offshore oil-drilling rigs and oil tankers, to ferryboats or other human targets, such as passenger cruise liners.

\section{Threats to U.S. Maritime Interests}

There is great concern in the United States about maritime terrorism taking the form of mass destruction or mass disruption warfare. This is primarily due to the fact that terrorist groups, and, principally Al-Qaeda, are actively targeting American maritime assets in both foreign and domestic waters. Al-Qaeda already has demonstrated a history of targeting American maritime vessels in foreign waters, as demonstrated by the attack against the USS Cole. The U.S. homeland's coastal areas represent another set of potential "trophy" targets to Al-Qaeda, given its modus operandi of continuous attempts to strike at the heart of the American economy and other symbolic targets, just as it did in the September 11 attacks against the World Trade Center. In this case, some 95 per-

\footnotetext{
62 "World Oil Transit Chokepoints," EIA Country Analysis Briefs, November 2002, at http://www.eia.doe.gov/cabs/choke.html.

${ }^{63}$ Ibid.
} 
cent of U.S. overseas trade is shipped by sea through more than 361 ports. $^{64}$ Moreover, many nuclear power plants are located in coastal areas (along with the majority of the U.S. population), making a waterborne attack against them a potential likelihood. In addition, American ports could be exploited by AlQaeda to smuggle a weapon of mass destruction into the U.S., given the difficulty of monitoring the more than 7,500 foreign-flag vessels that make some 51,000 annual port calls, and the 6 million loaded containers, including 156 million tons of hazardous material and one billion tons of petroleum products, that enter U.S. ports every year. ${ }^{65}$ This is one of the factors that has generated so much concern about the potential smuggling of a radiological "dirty" bomb in a loaded container that might evade detection.

Ports and loading terminals are, therefore, major targets for terrorist attack, especially ports that serve as transfer and offloading facilities for foreign oil being imported into the U.S. ${ }^{66}$ Facilities such as the Louisiana Offshore Oil Port, or LOOP, which is eighteen miles off the coast of Lafourche Parish, could be a potential target. ${ }^{67}$ The LOOP offloads 1.4 million barrels of foreign oil a day, or 15 percent of the nation's daily imported total. According to a report by the consulting firm Bracewell \& Patterson, the facility does have a counterterrorism plan, which was activated by the port's officials following September 11, and U.S. Coast Guard vessels are patrolling and conducting surveillance. ${ }^{68}$

As a result of these concerns, since the attacks against the World Trade Center and the Pentagon, the U.S. Coast Guard has been boarding "high interest" vessels bound for local terminals that carry hazardous cargo or arriving from suspicious countries. In New York, for example, the Coast Guard has been patrolling the Hudson River near the Indian Point nuclear power plant in Westchester and the vicinity of the Millstone nuclear plant on Long Island Sound in eastern Connecticut. ${ }^{69}$

\section{Potential Targeting of U.S. Cruise Industry}

Another maritime area of concern is the popular U.S. luxury liner cruise industry, which has enjoyed tremendous increases in passengers over the past decade. Moreover, new classes of mega-cruise ships are in service that exceed 140,000 gross tons, carrying upwards of 5,000 passengers and crew members ${ }^{70}$ - mak-

${ }^{64}$ Admiral James M. Loy, "Port and Maritime Security Strategy," statement before the Subcommittee on the Coast Guard and Maritime Transportation, U.S. House of Representatives, 6 December 2001. ${ }^{65}$ Ibid.

${ }^{66}$ Kathy Shirley, "Response to Terrorism Threat: Industry Re-examines Security Efforts," January 2002, at http://www.lioga.com/amogr_jan_industry.asp.

${ }^{67}$ Ibid.

${ }^{68}$ Ibid.

${ }^{69}$ Thomas Frank, "Coast Guard Faces New Security Role: Some Fear A Reduction of Boat-Safety Duties," Newsday, 16 June 2002.

${ }^{70}$ Admiral James M. Loy, "Seaports, Cruise Ships Vulnerable to Terrorism," Guest Commentary, 28 July 2001, at http://www.polticsol.com/guest-commentaries/2001-07-28.html. 
ing them desirable "trophy" targets to ambitious terrorist groups. A terrorist attack against such enormous ships would not only cause a catastrophic number of casualties, but would also threaten the entire cruise industry's economic viability. $^{71}$

In spring of 2002, the U.S. government issued a warning about the threat of "swimmers" possibly attaching incendiary devices to ship hulls. ${ }^{72}$ This was followed by a September 2002 speech by Stephen Ronchon, chief of intelligence for the U.S. Department of Transportation, warning that, "cruise ships were vulnerable to 'aerial attacks' from small planes." 73

The rapid spread of viruses on board cruise ships makes them easy targets for biological attacks. ${ }^{74}$ Although not terrorist related, outbreaks in 2002 of gastrointestinal illness associated with the Norwalk virus among passengers forced cruise lines such as Disney, Holland America, and Carnival to cancel or cut short several cruises. ${ }^{75}$

\section{The Next Phase in Maritime Terrorism}

In the next phase of maritime terrorism, in addition to the small, bomb-laden suicide craft (such as the vessel that damaged the USS Cole), terrorists could set their vessels' steering mechanism (like the remotely triggered truck bomb) on auto pilot to head to a harbor, or in the direction of a targeted ship, and after abandoning the vessel set it to explode. The next phase is also likely to feature the use of submarines (including mini-subs), vessels with stealth designs to reduce their exposure to radar, and the launching of weapons of mass destruction from vessels, with potentially catastrophic consequences. Another area of concern is terrorist hijacking or use of oil tankers or ships carrying liquefied gas for suicide missions. ${ }^{76}$ There is also a potential for state-sponsored maritime terrorism, such as providing terrorists with logistical support, a safe haven port, maritime training, and operational assistance in mining a shipping lane. Reportedly, Middle Eastern terrorist groups are influenced by the evolution in the Sri Lankan LTTE's maritime terror tactics and equipment, particularly in acquiring stealth vessels to more efficiently carry out maritime suicide terrorist attacks.

In terms of new trends arising from linkages between terrorist and criminal groups, there is great concern about the potential for criminal organizations, such as Balkan arms smugglers operating out of Albania, or others, to

\footnotetext{
${ }^{71}$ Ibid.

${ }^{72}$ Rick Newman, “Full Steam Ahead: In the New Age of 'What Ifs?' Here is What Cruise Lines Are Doing to Keep You Safe at Sea,” National Geographic Traveler, January/February 2003, 12.

${ }^{73}$ Ibid.

${ }^{74}$ Molly Feltner, National Geographic News, December 2002.

${ }^{75}$ Ibid.

${ }^{76}$ Eric Watkins, “Shipping Fraud Heightens Terror Threat," BBC News, 6 February 2002. www.guardian.co.uk
} 
provide a logistical infrastructure for terrorist groups to smuggle weapons of mass destruction from the former Soviet republics, via Eastern European suppliers, to the Middle East or other destinations.

\section{Conclusions}

With the successful terrorist attacks on the USS Cole and the Limburg, and several other foiled attempts to attack maritime targets, such as the Singaporean and Moroccan plots, terrorist groups are actively attempting to exploit the maritime environment to mount increasingly lethal attacks against U.S., Western, and other nations' military and commercial vessels. Israeli and U.S. shipping interests are the prime terrorist targets. In the case of the U.S., terrorists are likely to exploit any opportunity to punish the U.S. for its war on Al-Qaeda and the Taliban, and for detaining their fighters in Guantanamo Bay and in other detention centers around the world. As a result, we can expect active plotting by AlQaeda operatives against U.S. maritime interests either in the Mediterranean, the Red Sea, the Persian Gulf, East and Southeast Asia, and even against U.S. ports and coastlines, which would be considered the targets of highest symbolic significance. In a related trend, as U.S. naval combatant ships increase their readiness and deterrence posture in the Middle Eastern region, U.S.-flagged commercial ships will likely be attacked in their stead. Every effort should be made not only to prevent attacks similar to that against the USS Cole and the Limburg, but also to anticipate and preempt other targets of opportunity and new tactics and weaponry based on a thorough assessment of threat-related information about terrorist motivations, plans, and tactics.

Preparing to defend against the likelihood of increasingly lethal maritime terrorism is crucial, because terrorists are always searching for ways to exploit new adversary vulnerabilities, and maritime terrorism provides terrorist groups with a new and technologically advanced means to launch attacks against generally unsecured targets. Moreover, while extensive security precautions apply to air travel and important land installations, the civilian maritime industry is virtually unprotected, ports can be easily entered by vessels on a hostile mission, there is inadequate screening to board ships, terrorists can directly attack vessels or their crews in international waters, and can launch operations against shore targets by small boats, dinghies, submarines (including mini-submarines), or rocket-propelled boats. Furthermore, as terrorists and criminal groups increasingly cooperate in the maritime arena, it will be imperative for all the agencies responsible for protecting different components of maritime security whether law enforcement, drug interdiction, immigration, customs, and even military special forces - to cooperate as efficiently as possible in countering this threat. Such cooperation must, above all, extend to the international arena, so that all waterways and ports around the world will be safe and secure. 


\section{Bibliography}

Anderson, Sean K., and Stephen Sloan. Historical Dictionary of Terrorism. Lanham, MD and London: The Scarecrow Press , 2002.

Barzilai, Amnon, Daniel Sobelman, and Amira Hass. "Arms Boat Made Three Visits to Gaza." Ha'aretz (2001).

Binyon, Michael. "Deadly, Growing Scourge of Seas." The Times (2001).

Frank, Thomas. "Coast Guard Faces New Security Role: Some Fear A Reduction of Boat-Safety Duties." Newsday (2002).

Gunaratna, Rohan. "Sea Tiger Success Threatens the Spread of Copycat Tactics ." Jane's Intelligence Review (2001).

Gunaratna, Rohan. "Trends in Maritime Terrorism: The Sri Lankan Case ." Lanka Outlook (1998).

Newman, Rick. "Full Steam Ahead: In the New Age of 'What Ifs?' Here is What Cruise Lines Are Doing to Keep You Safe at Sea." National Geographic Traveler (2003).

Rubinstein, Danny. "Analysis: Weapons Were Meant for Many Fighters." Ha'aretz (2001).

Sakhuja, Vijay. Challenging Terrorism at Sea., 2002.

Shenon, Philip. "U.S. Expands Plan for Cargo Inspections at Foreign Ports." New York Times (2003).

Smith, Helena. "NATO 'Terror' Tipoff on Explosives Ship Sailing to Sudan." The Guardian (2003). 